\title{
Effect of Cinnamomum burmannii Stew on Glucose Fasting Blood Levels in Adult Prediabetes in Makassar
}

\author{
Nurhaedar Jafar ${ }^{1 *}$, Fadillah Nur Qalbi ${ }^{1}$, Ridwan M. Thaha², Veny Hadju ${ }^{1}$, Healthy Hidayanti ${ }^{1}$, Abdul Salam ${ }^{1}$, Aminuddin Syam $^{1}$ \\ ${ }^{1}$ Department of Nutrition, Faculty of Public Health, Hasanuddin University, Makassar, Indonesia; ${ }^{2}$ Department of Health \\ Promotion and Behavioral Sciences, Faculty of Public Health, Hasanuddin University, Makassar, Indonesia
}

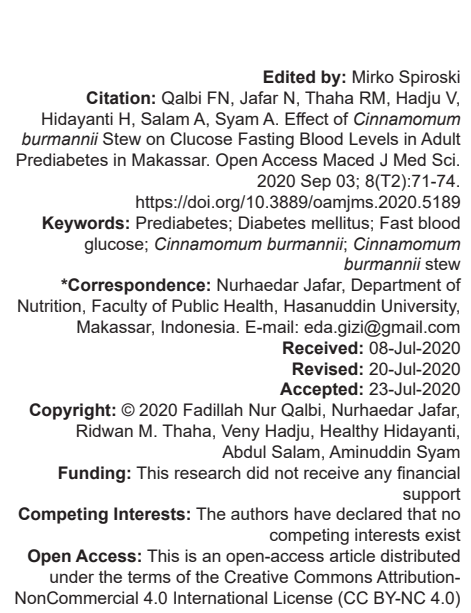

\section{Introduction}

Metabolic syndrome is a set of symptoms caused by a group of interconnected factors that can increase the risk of cardiovascular disease and type 2 diabetes mellitus (DM) [1]. Prediabetes is a condition where blood glucose levels are above normal, but have not yet reached the DM criteria. This condition is indicated by the occurrence of Impaired glucose tolerance (IGT) and impaired fasting glucose (IFG) and/or fasting blood glucose (glukosa darah puasa [GDP]) is disturbed [2].

Indonesia ranks third in the world after China and the US with the most prediabetes, which is 27.7 million [3]. Based on the Basic Health Research report in 2018 , there were $26.3 \%$ of the Indonesian population experienced impaired fasting glucose (100-125 mg / dL).

To help change the behavior of patients with prediabetes, it can be done by changing lifestyles such as food intake and physical activity and providing education. Health education regarding DM influences community behavior opportunities as indicated by a decrease in blood glucose levels after 3 months of education [5]. In addition to education, reducing blood sugar levels can be done by consuming cinnamon stew decoction.

Besides being safe, plants are cheaper and free of side effects [6]. One of the traditional medicinal plants that are believed to reduce blood glucose and lipid profile levels is Cinnamomum burmannii or cinnamon because it has a bioactive component of the polyphenol group which has an activity similar to insulin (mimetic insulin) [7].

Research conducted by Meida and Hellena [8] on the effect of cinnamon stew on fasting blood sugar levels showed results between differences before and after fasting blood sugar levels in patients with type 2 DM after being given interventions in the form of cinnamon stew at a dose of $10 \mathrm{mg}$. Cinnamon has a bioactive component of the polyphenol group that has activities similar to insulin (mimetic insulin) [9].

This cinnamon bark contains active substances, namely, polyphenols which work by 
increasing the insulin receptor protein in cells so that it can increase insulin sensitivity and decrease blood glucose levels to near normal. In addition, there are essential oils obtained only from the bark, namely, trans-cinnamaldehyde, eugenol, and linalool which have a percentage of $82.5 \%$ of the total composition [10].

This study aims to determine the effect of cinnamon stew on prediabetes adult fasting blood sugar levels in Makassar City.

\section{Materials and Methods}

This research was conducted in two working areas of the health center, Pampang health center, and Antara health center for 14 days of educational intervention and cinnamon stew. This research is a quasi-experimental design with randomized pre-test post-test with control group.

The population in this study is adult prediabetes in the working area of Pampang Health Center and Antara Makassar Health Center. The study sample was prediabetes adults in the Makassar City area who met the inclusion and exclusion criteria totaling 28 people. The sample was divided into two study groups: The intervention group (10 g cinnamon stew and education) and the control group (education without cinnamon stew) with a total sample of 14 people per group. The inclusion criteria of this study were those aged 40-60 years, had a GDP level of 100-125 mg/dl, and were willing to consume cinnamon stew every day for 14 days. While the exclusion criteria of this study are body mass index $(\mathrm{BMI})<17 \mathrm{~kg} / \mathrm{m}^{2}$, taking herbal medicines or from doctors who can control blood glucose levels, pregnant/breastfeeding women, and in sickness or in doctor's care.

Primary data obtained directly from interviews, questionnaires and laboratory results in the form of respondent characteristics data, data on fasting blood sugar levels, food intake of respondents, and knowledge level questionnaire. Secondary data were obtained from families and from other reference sources that support the research.

Data processing is performed using a SPSS computer program. A univariate test is performed on each variable to see an overview of its distribution and frequency. While the bivariate test was carried out by comparing the results of fasting blood glucose examination before and after the intervention was given using the Wilcoxon test and the Mann-Whitney test to test intergroup treatment. Furthermore, the data that have been obtained will be presented in the form of tables and graphs accompanied by narration.

\section{Results}

Table 1 shows that of the two groups, the majority of respondents were female, namely, 13 people $(92.9 \%)$ in the intervention group and 12 people $(85.7 \%)$ for the control group. For the age group can be seen for each intervention and control group most of the respondents in the early elderly group (46-55 years), as many as 11 people (78.6\%), for the control group as many as nine people (64.3). For the level of education, it can be seen that the educational characteristics for the intervention group are the highest, namely, four junior high school students and four academic students (28.6\%), and the most academic/control group is eight people $(35.7 \%)$.

Table 1: Characteristics of the prediabetes Society in the work area of the Pampang Health Center, and Antara Health Center Makassar City, 2019

\begin{tabular}{|c|c|c|c|c|c|c|}
\hline \multirow[t]{3}{*}{ Karakteristik } & \multicolumn{4}{|c|}{ Kelompok } & \multirow{2}{*}{\multicolumn{2}{|c|}{ Total }} \\
\hline & \multicolumn{2}{|c|}{ Intervensi } & \multicolumn{2}{|c|}{ Kontrol } & & \\
\hline & $\mathrm{n}$ & $\%$ & $\mathrm{n}$ & $\%$ & $n$ & $\%$ \\
\hline \multicolumn{7}{|l|}{ Jenis Kelamin } \\
\hline Laki-laki & 1 & 7.1 & 2 & 14.3 & 3 & 10.7 \\
\hline Perempuan & 13 & 92.9 & 12 & 85.7 & 25 & 89.3 \\
\hline \multicolumn{7}{|l|}{ Kelompok Umur } \\
\hline Dewasa Akhir (36-45 tahun) & 1 & 7.1 & 3 & 21.4 & 4 & 14.3 \\
\hline Lansia Awal (46-55 tahun) & 11 & 78.6 & 9 & 64.3 & 20 & 71.4 \\
\hline Lansia Akhir (56-65 tahun) & 2 & 14.3 & 2 & 14.3 & 4 & 14.3 \\
\hline \multicolumn{7}{|l|}{ Pendidikan } \\
\hline SD & 3 & 21.4 & 3 & 21.4 & 6 & 21.4 \\
\hline SMP & 4 & 28.6 & 2 & 14.6 & 6 & 21.4 \\
\hline SMA & 3 & 21.4 & 1 & 7.1 & 4 & 14.3 \\
\hline Academy/College & 4 & 28.5 & 8 & 57.1 & 12 & 32.2 \\
\hline \multicolumn{7}{|l|}{ Pekerjaan } \\
\hline PNS & 2 & 14.3 & 4 & 28.6 & 6 & 21.4 \\
\hline Wiraswasta & 1 & 7.1 & 6 & 42.9 & 7 & 25.0 \\
\hline Buruh & 1 & 7.1 & 0 & 3.6 & 1 & 3.6 \\
\hline IRT & 10 & 71.4 & 4 & 28.6 & 14 & 50.0 \\
\hline \multicolumn{7}{|l|}{ Status Perkawinan } \\
\hline Menikah & 14 & 100 & 12 & 85.7 & 26 & 92.9 \\
\hline Cerai mati & 0 & 0 & 2 & 14.3 & 2 & 7.1 \\
\hline \multicolumn{7}{|l|}{ Riwayat Keluarga DM } \\
\hline Ada & 9 & 64.3 & 11 & 78.6 & 20 & 71.4 \\
\hline Tidak Ada & 5 & 35.3 & 3 & 21.4 & 8 & 28.6 \\
\hline \multicolumn{7}{|l|}{ Obes Sentral } \\
\hline Normal & 1 & 7.1 & 1 & 7.1 & 2 & 7.1 \\
\hline Tidak normal & 13 & 92.9 & 13 & 92.9 & 26 & 92.9 \\
\hline \multicolumn{7}{|l|}{ Obes (IMT) } \\
\hline Normal & 0 & 0.0 & 1 & 7.1 & 1 & 3.6 \\
\hline Overweigh & 2 & 14.3 & 5 & 35.7 & 7 & 25.0 \\
\hline Obesitas & 12 & 85.7 & 8 & 57.1 & 20 & 71.4 \\
\hline
\end{tabular}

In Table 1, for occupation, the intervention group most of the respondents work as IRTs as many as ten people $(71.4 \%)$ for the control group the majority of respondents work as entrepreneurs, namely, six people (42.9\%). For marital status, most respondents have married status where the intervention group is 14 people $(100 \%)$ and in the control group is $12(85.7 \%)$. Family history, most respondents have a family history of DM, in the intervention group as many as nine people (64.3\%) and 11 people (78.6\%) for the control group.

In Table 1, for the characteristics of central obesity in the abdominal circumference of each group of respondents, both the intervention group and the control group were mostly of the central obesity status of 13 people each (92.9\%). For BMI, the intervention group was mostly obese, 12 people $(85.7 \%)$, and right people $(57.1 \%)$ for the control group. 
In Table 2, it can be seen that the Wilcoxon test results show that there is a significant difference between the levels of GDP before and after the intervention is given to the intervention group where $p$ value is $0.032<0.05$ while for the control group shows no significant difference between the levels of GDP before and after it is given intervention where $p$ value is $0.197<0.05$.

Table 2: Fasting Blood Glucose Analysis of Prediabetes Society in the work area Pampang's Health Center and Antara Health Center Makassar City, 2019

\begin{tabular}{llll}
\hline FBG $(\mathrm{mg} / \mathrm{dL})$ & Group & p-value \\
\cline { 2 - 3 } & Intervention Mean $\pm \mathrm{SD}$ & Control Mean $\pm \mathrm{SD}$ & \\
\hline Pre-intervention & $108.50 \pm 6.88$ & $110.93 \pm 7.79$ & $0.4899^{* *}$ \\
Post-intervention & $104.36 \pm 8.68$ & $108.43 \pm 9.18$ & $0.270^{* *}$ \\
Nilai $\mathrm{p}$ & $0.032^{*}$ & $0.197^{*}$ & \\
$\Delta$ FBG concentration & $-4.14 \pm 6.20$ & $-2.50 \pm 6.67$ & 0.506 \\
\hline${ }^{*}$ Uji Wilcoxon, ${ }^{*}$ *Uji Mann-Whitney. & &
\end{tabular}

Table 2 also shows that based on the results of the average Mann-Whitney test for GDP levels in the two groups before the intervention, there is no significant difference where $p$ value is $0.489>0.05$, indicating that the average GDP level of the respondents before the intervention is homogeneous between groups. The mean GDP levels in the two groups after the intervention also showed no significant difference where $p$ value was $0.270>0.05$.

Table 2 also shows that based on the results of the average Mann-Whitney test for GDP levels in the two groups before the intervention, there is no significant difference where $p$ value is $0.489>0.05$, indicating that the average GDP level of the respondents before the intervention is homogeneous between groups.

Table 2 also show the mean GDP levels in the two groups after the intervention also showed no significant difference where $p$ value was $0.270>0.05$. Based on the magnitude of the difference in levels of GDP, before the intervention and after the intervention in the intervention group was $-4.14 \pm 6.20$, in the control group was $-2.50 \pm 6.67$, the same results for the difference in the average levels of GDP before and after the intervention showed no there was a significant difference between the two groups where $p$ value was $0.506>0.05$.

In Table 2, the differences in GDP levels between the two intervention and control groups after the intervention also showed no significant difference where $p$ value was $0.270>0.05$.

\section{Discussion}

This study shows the effect of giving cinnamon stew on the GDP of prediabetes patients. There was a significant change in the GDP of the intervention group after the intervention, for the control group there was a decrease in the level of GDP but not significant after the provision of educational intervention, whereas for between groups there was no significant difference in GDP levels between the intervention group and the control group.

Judging by the results for the level of knowledge of the intervention group has increased after being given education, this is because respondents were able to find out about prediabetes, how to arrange food to reduce blood sugar levels and the benefits of cinnamon for reducing blood sugar levels. This study is in line with Tim et al. [11] in Lakeland Florida about the Effects of Soluble Cinnamon Extract on Body Composition and Metabolic Syndrome in Pre-Diabetes Men and Women showing the results of a decrease in fasting blood sugar levels.

This study is also in line with the study of Meida and Hellena [8] on the Effect of Cinnamon Stew (C. burmannii on Fasting Blood Sugar Levels of Type 2 DM Patients showing results after drinking cinnamon stew for 3 days in a dose of $10 \mathrm{mg}$ showed significant results with $p=0.006<\alpha$ [0.05]). Similar study by Arini and Ardiaria [12] with the results that there were significant changes $(p<0.05)$ in all three test groups, with the most significant changes being in the $10 \mathrm{~g}$ group with a correlation level of 0.000 and the group 8 $\mathrm{g}$ with a correlation of 0.001 .

Cinnamon is a plant that has flavonoid content [13] The workings of flavonoid compounds have been shown to have beneficial effects in fighting diabetes, both through the ability to control blood sugar levels and optimize the work of the pancreatic organs by increasing the sensitivity of pancreatic beta cells to produce the insulin hormone needed to regulate blood glucose levels in the body [14].

In addition, the main polyphenol components in cinnamon include cinnamic acid and ferulic acid, both of which have m-hydroxy and p-methoxy residues in the phenol ring structure having significant activity on pancreatic function at a concentration of $1 \mu \mathrm{M}$ [15]. Increased glucose uptake and slows hepatic gluconeogenesis with no effect from pancreatic insulin output [16]. Asan cinnamat has the same effect as cinnamaldehyde, which can be insulin secretion, increase glucokinase activity and glycogen levels, thereby suppressing the occurrence of gluconeogenesis and glycogenolysis that occurs in the liver [17].

Table 2 also shows the results for the control group given education shows that the mean change in fasting blood sugar levels decreased from 110.93 to 108.43 but statistically not significant $(p=0.197)>0.05$ which means there is no difference between before and after providing education. This is because the control group did not consume cinnamon stew to help reduce blood sugar levels.

These results are in line with the results of the study of Norris et al. [18] who said that education is important in the treatment of DM patients where 
the provision of education can control blood gamma hydroxybutyrate $(\mathrm{GHb})$ in respondents $(0.76 \%)$, whereas without the provision of controlled $\mathrm{GHb}$ education only $(0.26 \%)$. This knowledge can be enhanced by forming confidence in oneself so that someone can behave in accordance with daily life [19], [20].

For changes in GDP between the intervention group and the control group, then seen from the large difference in changes between the intervention groups and the control group is statistically insignificant where the value $(p=0.506)$ which means there is no difference in change between the intervention group and the control group but in each group decreased but a greater change occurred in the intervention group where the value of the difference was 4.14 compared to the control which was 2.50 .

For between groups the mean difference in GDP levels in the two groups after the cinnamon stew intervention and education, there was no significant difference where $p=0.270>0.05$ indicating there was no change in fasting blood sugar levels between the intervention group and the control group after the intervention. This is because the time of intervention of cinnamon stew in the intervention group is still lacking so the difference is still less visible.

\section{Recommendation}

The level of involvement is one of the impacts in the implementation of a healthy city consisting of two indicators. An evaluation of the two indicators gave satisfactory results. The involvement of stakeholders in this matter is that women have been quite active and participatory. Besides that, the political commitment of the Makassar city government itself has succeeded in bringing satisfactory results to the development of the city. However, it is recommended for each Regional work units at the city government level to further improve coordination with each other, because there are still overlapping tasks between each SKPD.

\section{References}

1. Kassi E, Pervanidou P, Kaltsas G, Chrousos G. Metabolic syndrome: Definitions and controversies. J Med. 2015;9(1):4850. https://doi.org/10.1186/1741-7015-9-48 PMid:21542944

2. Aeronautical Development Agency. American diabetes association standards of medical care in diabetes (ADA) 2018. Diabetes Care. 2018;41(13):14-80.

3. Arulselvan GG, Karthivashana MF, Halima MS, Ghafara HA, Fakurazi S. Antidiabetic therapeutics from natural sources. J BioMed Prevent Nutr. 2014;4(4):607-17. https://doi. org/10.1016/j.bionut.2014.07.009

4. Kemenkes RI. Riset Kesehatan Dasar (Riskesdas) 2018.
Jakarta: Kementerian Kesehatan Republik Indonesia; 2018.

5. Triastuti NJ. The effect of health education on diabetes mellitus on changes in the behavior of the villagers of Bulan, Wonosari, Klaten. J Biomed. 2010;1(2):38-41.

6. Mukherjee PK, Houghton PJ. Leads from Indian medical plants with hypoglicemic potensials. J Ethnopharmacol. 2011;28(1):80-9.

7. Erni H. Diabetes Kandas Berkat Herbal. Jakarta Selatan: Imprint Agno Media Pustaka; 2013.

8. Meida WY, Helena D. The effect of cinnamon decoction on fasting blood sugar levels of people with Type 2 diabetes mellitus. Stud Online J Med Fac. 2018;6(1);28-33. https:doi. org/10.22219/sm.vol14.smumm2.6246.

9. Richard A, Rencai L, Xiuhua G, Qingqing G, Jin Z, Jiang $\mathrm{K}$, et al. Cinnamon extract lowers glucose, insulin and cholesterol in people with elevated serum glucose. J Tradit Complement Med. 2016;6(4):332-6. https://doi.org/10.1016/j. jtcme.2015.03.005

PMid:27774415

10. Nurwati AD, Abdurachman A. Particleboard properties of cinnamon bark. For Prod Res J. 2011;29(2)75-83. https://doi. org/10.20886/jphh.2011.29.2.128-141

11. Tim JE, Ronald WM, Jamie L, Richard AA. Effects of a water-soluble cinnamon extract on body composition and features of the metabolic syndrome in pre-diabetic men and women. J Int Soc Sports Nutr. 2016;3(2):45-53. https://doi. org/10.1186/1550-2783-3-2-45 PMid:18500972

12. Arini JP, Ardiaria M. The effect of brewing cinnamomum (Cinnammomum zeylanicum) powder on fasting blood glucose levels 2 hours post prandial in people with Type 2 diabetes. Stud Sci J Univ Diponegoro. 2016;33(2):127-30. https://doi. org/10.30633/jkms.v10i1.311

13. Ningsih IY. The role of entnopharmaceutical studies in the search for medicinal plants that have the potential to be developed as anti-diabetes. J Pharm. 2015;31(2):755-8.

14. Indrawati NL. Bawang Dayak Si Umbi Ajaib Penakluk Aneka Penyakit. Jakarta: PT Agromedia Pustaka; 2013.

15. Molly E, Howard ND. Potential benefits of cinnamon in Type 2 diabetes. Am J Lifestyle Med. 2013;7(23):77-83.

16. Jakhetia VR, Khantri O, Pahuja N, Garg S, Pandey A Sharna S. Cinnamon: A pharmacological review. J Adv Sci Res. 2016;1(2):19-23.

17. Crawford $P$, Nellis $F$, Mike OC. Effectiveness of cinnamon for lowering hemoglobin $\mathrm{A} 1 \mathrm{C}$ in patients with Type 2 diabetes: A randomized, controlled trial. J Am Board Fam Med. 2009;22(5):507-12. https://doi.org/10.3122/ jabfm.2009.05.080093 PMid:19734396

18. Norris SL, Lau J, Smith SJ. Self-management education for adults with Type 2 diabetes a meta-analysis of the effect on glycemic control. J Diabetes Care. 2012;25(7):1159-71. https:// doi.org/10.2337/diacare.25.7.1159 PMid: 12087014

19. Mallongi A, Novitasari DA, Noor NB, Fatmawati, Saleh M, Sehalyana, et al. Health risk analysis of phenol and arsenic exposure among kokoda communities village Sorong, West Papua. Enfermer Clín. 2020;30(Suppl 4):123-6. https://doi. org/10.1016/j.enfcli.2019.10.055 PMid:32545028

20. Blouza CS, Jamoussi KH, Ben MA, Abid A, Loueslati F, Khelifi N, et al. The effect of nutritional education on the food intake regulation of the young diabetic. Tunis Med. 2014;78(10):595-9. PMid:11190745 